\title{
Optimization of callus and cell suspension cultures of Barringtonia racemosa (Lecythidaceae family) for lycopene production
}

\author{
Mandana Behbahani1 ${ }^{1 *}$; Mehrnaz Shanehsazzadeh ${ }^{2}$; Mohamad Javad Hessami ${ }^{1}$ \\ ${ }^{1}$ University of Isfahan/Faculty of Advanced Sciences and Technologies - Dept. of Biotechnology - 81746-73441 - \\ Isfahan, I.R. - Iran. \\ ${ }^{2}$ Park Research Laboratory, $n^{\circ}$. 3, 2nd fl., Golestan Building, Chabarbagh-bala St., Isfahan - Iran. \\ *Corresponding author <Ma_behbahani@yaboo.com>
}

\begin{abstract}
Lycopene is present in a range of fresh fruits and vegetables, especially in the leaves of Barringtonia racemosa. The traditional lycopene extraction from the plant is being employed instead of an easy propagation technique like cell culture process from the leaf explants. We intend to assess how lycopene could be extracted via tissue culture under light (illuminance: 8,200 lux under white fluorescent lamps, photoperiod $16 \mathrm{~h}$ per day at $25^{\circ} \mathrm{C}$ ) and dark. Leaf explants of Barringtonia racemosa were cultured on modified Murashige and Skoog (MS), Woody Plant Medium (WPM) and B5 media, supplemented with different concentrations of 2,4Dichlorophenoxyacetic acid (2,4-D). Optimal conditions for callus induction and maintenance under both dark and light were investigated, and growth and lycopene accumulation were evaluated. Among media with different concentrations of 2,4-D, fast growing, friable callus initiated within three weeks after culturing on WPM basal medium supplemented with $2.0 \mathrm{mg} \mathrm{L}^{-1}$ (weight per volume) of 2,4-D, whereas callus induction in explants cultured on all other media started only after five weeks. Calli were subcultured once every fortnight. Pale yellow and green calli developed under conditions of dark and light respectively were then selected for evaluation of their lycopene contents. An improved reversed phase of high performance liquid chromatography (HPLC) method was used for a selective chemical determination of the lycopene content. Light induced lycopene production; and likewise maximum lycopene level incubated in light was higher than those incubated in darkness. The best growth rates of callus and cell suspension were achieved in WPM and B5 media respectively. The production of lycopene was growth-dependent through analysis of growth and lycopene content of both callus and cell suspension cultures.
\end{abstract}

Key words: Powderpuff tree, carotene, phytochemical, plant micropropagation, growth hormones

\section{Otimização de culturas de suspensões de calos e células de Barringtonia racemosa (família Lecythidaceae) para produção de licopeno}

\begin{abstract}
RESUMO: O licopeno está presente numa série de frutas frescas e hortaliças principalmente na folhas de Barringtonia racemosa. A extração tradicional do licopeno tem sido empregada no lugar da fácil técnica de propagação como o processo de cultura de células de explantes de folhas. E nossa intenção demonstrar como o licopeno pode ser extraído através de cultura de tecido sob luz (iluminação com lâmpadas fluorescentes brancas de 8.200 lux, 16 h por dia a $25^{\circ} \mathrm{C}$ ) e escuro. Explantes de folhas de Barringtonia racemosa foram cultivados em meio modificado de Murashige e Skoog (MS) para plantas lenhosas e meio B5, suplementado com diferentes concentrações de ácido 2,4-Diclorofenoxiacético (2,4-D). Condições ótimas para indução e manutenção de calos sob luz e escuro foram investigadas e avaliados o crescimento e acumulo de licopeno. Entre meios com diferentes concentrações de 2,4-D, calos friáveis de crescimento rápido tiveram início em três semanas após serem cultivados em meio basal WPM suplementado com $2.0 \mathrm{mg} \mathrm{L}^{-1}$ (peso por volume) de 2,4-D enquanto indução de calos em explantes cultivados em todos os outros meios começaram somente após cinco semanas. Calos foram subrepicados a cada 15 dias. Calos amarelo-pálido e verdes desenvolvidos respectivamente sob condições escura e de luz foram então selecionados para avaliação do teor de licopeno. Um método aperfeiçoado de cromatografia líquida de alto desempenho foi usado para a determinação química seletiva do teor de licopeno. A produção de licopeno induzida sob luz e também o nível máximo de licopeno incubado em luz foi mais alto do que aqueles incubados no escuro. As melhores taxas de crescimento de calo e suspensões de células foram obtidas respectivamente em meio WPM e B5. A produção de licopeno dependeu do crescimento como demonstrado pela análise do crescimento e teor de licopeno de ambos calos e cultura de células em suspensão. Palavras-chave: Mimosa, caroteno, fitoquímico, micropropagação de plantas, hormônios de crescimento
\end{abstract}

\section{Introduction}

Barringtonia racemosa, (Lecythidaceae family) with natural habitat of the West Coast of India, Sundarbans, Assam, Andaman Islands and Malaysia (Thomas et al., 2002) is a traditional medicine in Malaysia. The fruits

Sci. Agric. (Piracicaba, Braz.), v.68, n.1, p.69-76, January/February 2011 
are used to treat cough, asthma and diarrhea and the seeds for treatment of colic, jaundice and ophthalmic disorders (Behbahani et al., 2007b; Khan et al., 2000; MacKeen et al., 1997). The bark ethanol extract has antitumor property in mice (Khan et al., 2000), but the leaf ethanol extract displayed cytotoxicity against the HelA (human cervical carcinoma) cell lines with $\mathrm{IC}_{50}$ value of $10 \mu \mathrm{g} \mathrm{mL}^{-1}$ (MacKeen et al., 1997). The stem aqueous extract has antinociceptive and toxicological effect on rats (Thomas et al., 2002) while the roots ethanol extract provided two novel neo-clerodane-type diterpenoids Nasimaluns A and B by NMR and MS data analysis (Khan et al., 2000). The active compound responsible for the anti-oxidant and anti-inflammatory properties of the leaves was found to be lycopene and B. racemosa is one of the most important sources of this compound compared to any other reported plants (Behbahani et al., 2007b). This most predominant carotenoid is a potent in vitro scavenger of singlet oxygen as an antioxidant. Zhao et al. (2003) found lycopene as a compound with excellent anti-inflammatory or antioxidant properties in mice taking part in protecting animals against damage from free radicals. The suppression of cancer cell growth was proved in vitro and in animal studies. Human studies showed remarkable benefits from elevated lycopene levels both in diet and in the body (Welsch et al., 2001).

There are few reports on cell culture as a strategy for lycopene production, which is usually extracted directly from plant tissue. Cell culture is a simple and cost-effective method for lycopene production compared to direct extraction (Behbahani et al., 2007a) whereas only two or three compounds are isolated from cell culture, almost 20 compounds should be isolated to obtain lycopene through direct extraction of plant tissues. Therefore, the purpose of the current study was to develop laboratory cell culture process starting from leaf explants.

\section{Material and Methods}

Young leaves $(5.7 \times 3.5 \mathrm{~cm})$ of Barringtonia racemosa were collected from 2-month old seedling grown in a greenhouse in Serdang, Selangor, Malaysia. After surface sterilization with $70 \%$ (volume per volume) ethanol for 1 min, leaf explants were immersed for $20 \mathrm{~min}$ in $5.25 \%$ (weight per volume) sodium hypochlorite solution containing one drop of polyoxyethylene sorbitan monooleate. Then, they were rinsed four times with sterile distilled water. For callus induction, the leaves were aseptically cut into small pieces $(0.5 \times 0.5 \mathrm{~cm})$. Sterile explants were aseptically inoculated on various nutrient media including Murashige and Skoog (1962) medium (MS), woody plant medium (WPM, Pavingerova and Sediva, 1999) and B5 medium containing its special microelements and vitamins, (B5, Gamborg et al., 1968) supplemented with concentrations of 2,4-Dichlorophenoxyacetic acid (2,4-D, 0.5$3 \mathrm{mg} \mathrm{L}^{-1}$ ). Each basal medium contained $30 \mathrm{~g} \mathrm{~L}^{-1}$ (weight per volume) sucrose and $7 \mathrm{~g} \mathrm{~L}^{-1}$ (weight per volume) agar (Sigma Type A, Germany). The $\mathrm{pH}$ of the media was adjusted to 5.7 with $1 \mathrm{M} \mathrm{NaOH}$ solution.
The medium was then autoclaved at $121^{\circ} \mathrm{C}$ for 15 min. The explants were incubated at $25^{\circ} \mathrm{C}$ in dark and light (illuminance: 8200 lux under white fluorescent lamps, photoperiod $16 \mathrm{~h}$ per day) for five weeks. Then, three media of WPM, B5 and MS medium supplemented with different concentration of growth regulators were investigated in this experiment and five repeats on each medium (ten callus per repeat lycopene production and profile of callus growth) were performed for six weeks at $25^{\circ} \mathrm{C}$ under dark and light condition to investigate the factors influencing the callus induction. Then, the percentage of explants producing callus was recorded. The establishment of callus induction was based on the best dry weight in fifth week (Figure 2). The observation was made on the morphology of callus induced by different ranges of concentration of external phytohormone 2,4$\mathrm{D}$ which were used.

Establishment of cell suspension cultures were carried out by using $2 \mathrm{~g}$ (fresh weight) of five-week old friable callus derived from leaf of $B$. racemosa in $25 \mathrm{~mL}$ liquid suspension medium (basal WPM or B5 or MS liquid medium, pH 5.7 supplemented with $3 \%$ (weight per volume) sucrose and $2 \mathrm{mg} \mathrm{L}^{-1}$ 2,4-D) in $100 \mathrm{~mL}$ Erlenmeyer flasks. The cultures were agitated at $100 \mathrm{rpm}$ on an orbital shaker. Half of them were incubated in light (Photoperiod: 16h light/8h dark, flux: 8,200 lux at $25^{\circ} \mathrm{C}$ under white fluorescent lamps) and the other half in the dark.

The cell were separated after ten days, and the fresh and dry weight (Oven: $40^{\circ} \mathrm{C}$ ) of the cell were measured. Every week, subculturing was done by transferring $5 \mathrm{~mL}$ batch of suspension cultures to $20 \mathrm{~mL}$ of the above mentioned media before shaking and incubation as earlier. From the stock cultures, $25 \mathrm{~mL}$ (approx. $0.5 \mathrm{~g}$ fresh weight) of the cell inoculums in $100 \mathrm{~mL}$ of fresh liquid medium were divided in five Erlenmeyer flasks and this was repeated three times. They were sampled at one week intervals over six weeks to determine dry weights and lycopene production as well as to plot growth curves of the cell suspension cultures at different growth rate of cell suspension found in three basal WPM, B5 and MS media.

Lycopene was extracted from $0.5 \mathrm{~g}$ oven-dried at $40^{\circ} \mathrm{C}$ powdered yellow and light green callus as well as cell suspensions using $50 \mathrm{~mL}$ of $95 \%$ (weight per volume) chloroform in a Soxhlet apparatus. The filtered extract was then reduced to about $5 \mathrm{~mL}$ under vacuum for HPLC analysis. The lycopene content of the sample was calculated using the formula as given below:

An Optical Density (OD) of $1=3.1206 \mu \mathrm{g}$ of lycopene per $\mathrm{mL}$.

Formula for lycopene content:

$\mathrm{Mg}$ of lycopene $/ \mathrm{g} \mathrm{DW}=\underline{3.1206 \times \mathrm{OD} \text { of sample } \times \text { volume made up } \times \text { Dilution factor }}$ $1 \times$ Weight of Sample $\times 100$

For preparation of standard lycopene (Figure 1), 1 $\mathrm{mg}$ of lycopene (Sigma,USA) standard was separately 
dissolved in $1 \mathrm{~mL}$ of absolute HPLC grade chloroform (Sigma, Germany). The carotenoid standard (lycopene) prepared was kept in a screw cap small dark bottle (2 $\mathrm{mL}$ ) and refrigerated at $4{ }^{\circ} \mathrm{C}$ until used.

HPLC was performed on a HITACHI Series HPLC system equipped with L-7100 pump and an L-7100 UVvis detector. Peaks were separated on a Diamonsil $\mathrm{C}_{18}$ column using the mobile phase [acetonitriledichloromethane $(75: 25$, volume per volume)]. The flowrate of the mobile phase was $1.5 \mathrm{~mL} \mathrm{~min}^{-1}$. The absorption of analytes was detected at $450 \mathrm{~nm}$. Samples were injected on to the HPLC bed manually with injection volume as $5 \mu \mathrm{L}$ or as stated otherwise. T2000 software was used for peak integration and calculation. To identify the peaks, the spectral patterns and retention time of the samples were compared with standard. Lycopene was quantified by comparing the peak area and retention time obtained for the extracted sample with the peak area and retention time of appropriate standard lycopene. The content of lycopene in the samples was calculated using the following equation.

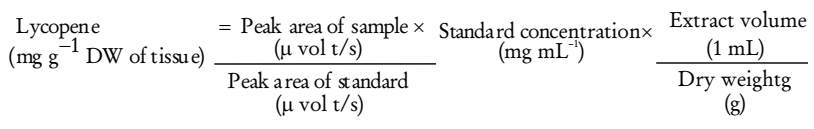

For statistical analysis, normal distribution of the data (variance homogeneity test) was tested. Then, a factorial experiment in a Complete Randomized Design (CRD) were analyzed using two way techniques of analyses of variance (ANOVA) by software SAS version $6.12(p<0.05)$. We performed analysis of variance of callus induction of $B$. racemosa from leaf explants (after six weeks of culture) on WPM medium supplemented with different levels of 2,4-D under dark and light and also analysis of variance of lycopene content of extracts of in vitro callus and cell suspension of $B$. racemosa. When $p<0.05$, Duncan Multiple Range Test (DMRT) was used to separate means. Each treatment was independent and contained five replicates with ten explants per replicate. Means and standard errors were used for statistical analysis.

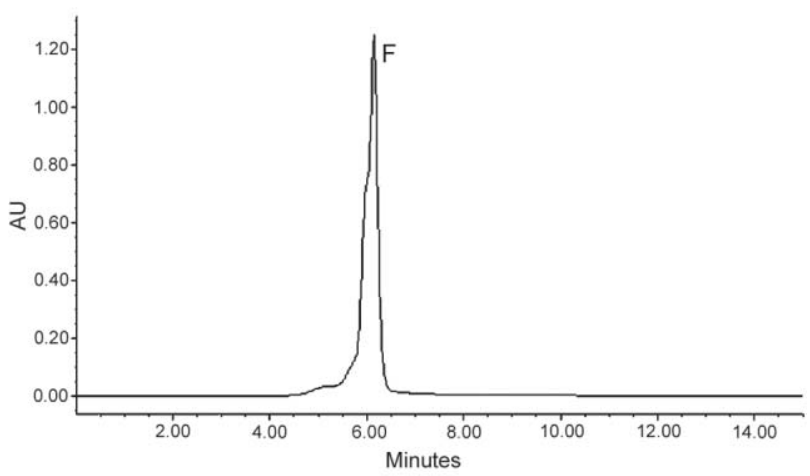

Figure 1 - HPLC chromatogram of standard lycopene spectra detected by UV-1570 detector at $450 \mathrm{~nm}$ using acetonitrile, dichloromethane solvent system at the flow rate of $1 \mathrm{~mL} \mathrm{~min}^{-1}$. F indicates standard lycopene peak.

Table 1 - Days for callus initiation, percentage of callus induction, and morphology of callus formed from Barringtonia racemosa leaf explants on WPM, B5 and MS media ( $\mathrm{pH}$ 5.8) supplemented with different levels of 2,4-D supplied after 35 days of cultures at $25^{\circ} \mathrm{C}$ under dark and light.

\begin{tabular}{|c|c|c|c|c|c|c|}
\hline \multirow{2}{*}{$\begin{array}{l}\text { Medium plus 2,4-D } \\
\text { Concentrations }\end{array}$} & \multicolumn{2}{|c|}{ Days for callus initiation } & \multicolumn{2}{|c|}{ Biomass for dried weight after five weeks } & \multicolumn{2}{|c|}{ Callus induction after five week } \\
\hline & Dark & Light & Dark & Light & Dark & Light \\
\hline $\mathrm{mg} \mathrm{L}^{-1}$ & & & gDW & 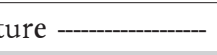 & (2) & - \\
\hline WPM+ & - & - & - & - & - & - \\
\hline $\mathrm{WPM}+0.5$ & $21 \pm 2$ & $24 \pm 2$ & $4.2 \pm 0.1^{\mathrm{d}}$ & $3.7 \pm 0.1^{\mathrm{d}}$ & $34 \pm 2^{\mathrm{e}}$ & $24 \pm 2^{\mathrm{e}}$ \\
\hline $\mathrm{WPM}+1$ & $21 \pm 2$ & $23 \pm 2$ & $7.2 \pm 0.2^{c}$ & $5.8 \pm 0.3^{c}$ & $65 \pm 2^{c}$ & $55 \pm 3^{c}$ \\
\hline $\mathrm{WPM}+2$ & $20 \pm 1$ & $23 \pm 1$ & $12.4 \pm 0.4^{a}$ & $9.9 \pm 0.4^{a}$ & $90 \pm 2^{a}$ & $78 \pm 1^{a}$ \\
\hline $\mathrm{WPM}+3$ & $21 \pm 2$ & $24 \pm 2$ & $10.2 \pm 0.4^{b}$ & $7.9 \pm 0.3^{b}$ & $75 \pm 2^{b}$ & $67 \pm 2^{b}$ \\
\hline $\mathrm{B} 5+0$ & - & - & - & - & - & - \\
\hline $\mathrm{B} 5+0.5$ & $24 \pm 2$ & $26 \pm 2$ & $3.2 \pm 0.2^{\mathrm{e}}$ & $2.1 \pm 0.1^{\mathrm{e}}$ & $27 \pm 1^{\mathrm{e}}$ & $21 \pm 2^{\mathrm{e}}$ \\
\hline $\mathrm{B} 5+1$ & $23 \pm 2$ & $25 \pm 2$ & $5.5 \pm 0.3^{\text {cd }}$ & $4.6 \pm 0.2^{\mathrm{cd}}$ & $53 \pm 1^{\mathrm{d}}$ & $43 \pm 2^{\mathrm{d}}$ \\
\hline $\mathrm{B} 5+2$ & $23 \pm 1$ & $25 \pm 2$ & $9.3 \pm 0.4^{b}$ & $6.1 \pm 0.3^{c}$ & $72 \pm 2^{b}$ & $61 \pm 2^{b}$ \\
\hline $\mathrm{B} 5+3$ & $23 \pm 2$ & $25 \pm 2$ & $7.4 \pm 0.4^{c}$ & $5.2 \pm 0.3^{c}$ & $60 \pm 2^{c}$ & $53 \pm 2^{c}$ \\
\hline $\mathrm{MS}+0$ & - & - & - & - & - & - \\
\hline $\mathrm{MS}+0.5$ & $29 \pm 1$ & $31 \pm 1$ & $1.2 \pm 0.1^{f}$ & $0.5 \pm 1^{f}$ & $13 \pm 1^{\mathrm{e}}$ & $10 \pm 1^{\mathrm{e}}$ \\
\hline $\mathrm{MS}+1$ & $28 \pm 2$ & $30 \pm 1$ & $2.5 \pm 0.1^{\mathrm{e}}$ & $1.3 \pm 0.1^{\text {ef }}$ & $32 \pm 1^{\mathrm{d}}$ & $27 \pm 1^{\mathrm{d}}$ \\
\hline $\mathrm{MS}+2$ & $28 \pm 1$ & $30 \pm 2$ & $4.1 \pm 0.2^{\mathrm{d}}$ & $2.2 \pm 0.1^{\mathrm{e}}$ & $48 \pm 2^{\mathrm{d}}$ & $43 \pm 1^{\mathrm{d}}$ \\
\hline $\mathrm{MS}+3$ & $29 \pm 2$ & $30 \pm 2$ & $3.5 \pm 0.2^{\mathrm{de}}$ & $0.5 \pm 0^{f}$ & $40 \pm 2^{\mathrm{d}}$ & $32 \pm 2^{\mathrm{d}}$ \\
\hline
\end{tabular}

Means with the same letter were not different $(p<0.05$, DMRT test). PY: pale yellow, LG: light green. 


\section{Results}

During the third week some calli developed in WPM medium supplemented with $2 \mathrm{mg} \mathrm{L}^{-1}$ (weight per volume) 2,4-D, (20 days \pm 1 sd) (Table 1$)$. WPM resulted in a higher percentage of callus induction (Table 1); WPM medium was supplemented with $2 \mathrm{mg} \mathrm{L}^{-1}$ (weight per volume) 2,4-D treatment which was observed to yield more callus $(90 \%$, dry weight: $12.4 \pm 0.4)$ compared to other treatments in dark condition $(p<0.05)$. A direct correlation was observed between callus induction and the dry weight among treatments (Table 1). Conversely, the percentage of callus induction and also friability were generally lower in MS medium. MS medium containing different concentrations of 2,4-D led to the production of compact callus. The callus initiated in medium with combination of $0.5-3 \mathrm{mg} \mathrm{L}^{-1}$ of $2,4-\mathrm{D}$ treatments which were initially turned pale yellow by incubation in the dark but turned to light green in light. Growth rate of $B$. racemosa callus was high at the fifth week $(0.12 \pm 0.002$ and $0.096 \pm 0.001 \mathrm{~g} \mathrm{DW}$ per culture for dark and light, respectively) while cell suspension was $0.134 \pm 0.0037$ and $0.122 \pm 0.0038 \mathrm{~g} \mathrm{DW}$ per culture in dark and light in the fourth week, respectively.

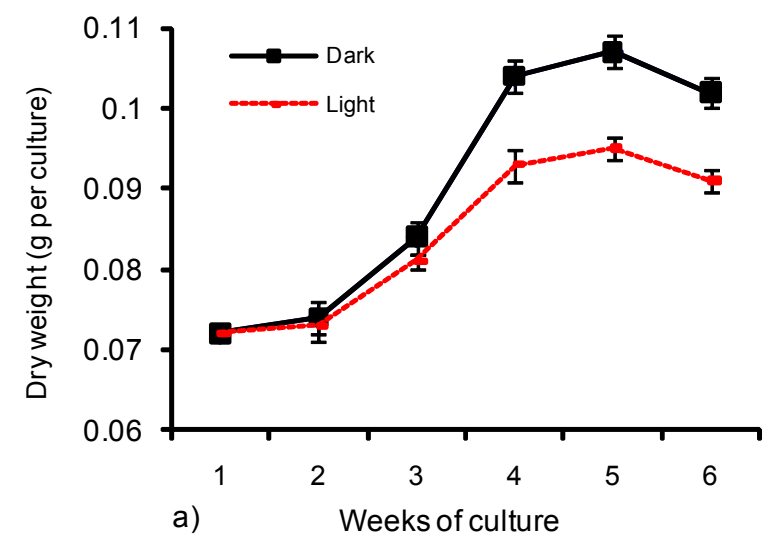

Figure 2 - Profile of growth of Barringtonia racemosa callus (a) and lycopene production (b) in leaf derived callus of Barringtonia racemosa cultured on basal WPM medium supplemented with $2 \mathrm{mg} \mathrm{L}^{-1}(\mathrm{w} / \mathrm{v})$ 2,4-D incubated at $25^{\circ} \mathrm{C}$ in light and dark conditions. Data indicate as mean \pm standard deviation $(\mathrm{n}=5)$.
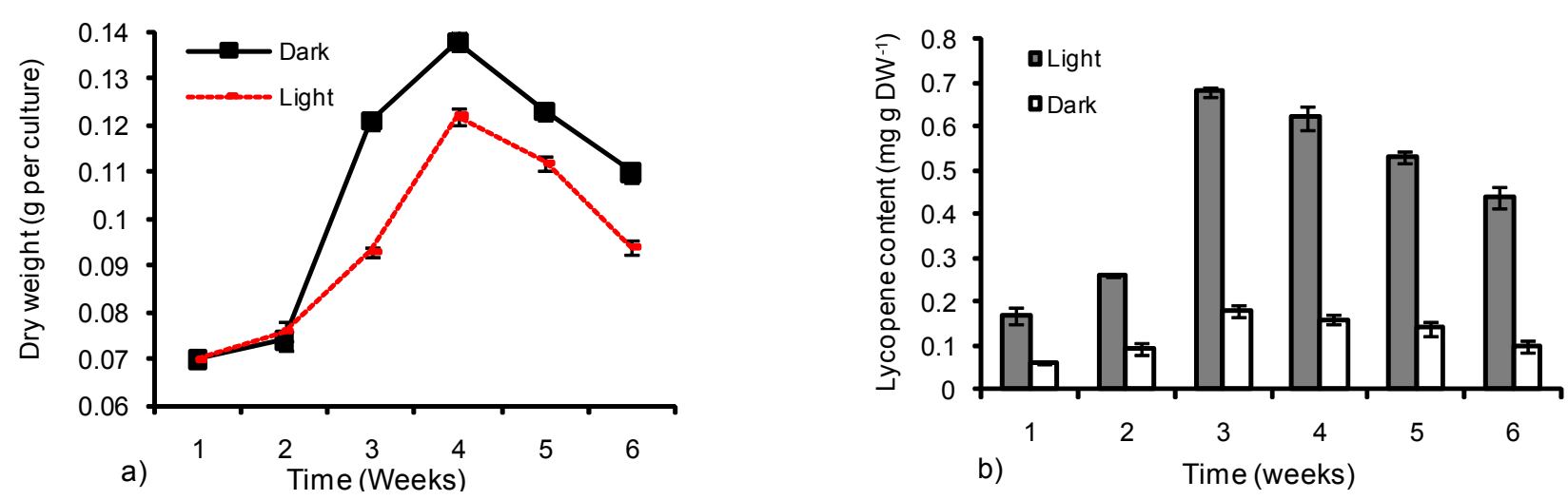

Figure 3 - Profile of growth of Barringtonia racemosa cell suspension (a) and lycopene production (b) in leaf derived cell suspension of Barringtonia racemosa cultured on basal B5 medium supplemented with $2 \mathrm{mg} \mathrm{L}^{-1}(\mathrm{w} / \mathrm{v}) 2,4-\mathrm{D}$ incubated at $25^{\circ} \mathrm{C}$ in light and dark conditions. Data indicate as mean \pm standard deviation $(n=5)$. 
B5 (dry weight: $9.3 \pm 0.4 \mathrm{~g}$ ) media, respectively. The dry weight of callus incubated in the dark and light also increased rapidly during the $1^{\text {st }}$ week of incubation which reached its maximum growth rate (stationary growth phase) in the $5^{\text {th }}$ week in all media. Finally, the callus growth decreased. After six weeks, the callus subsequently started to wither and turn brown.

WPM medium was the best for callus growth yielding $0.105 \mathrm{~g}$ per culture of calli (Figure $4 \mathrm{a}, \mathrm{b}$ ). This was followed by B5 and MS media in light and dark, respectively. Similarly for lycopene production in Figure 4 (c, d), the callus cultured on WPM basal medium were found to have a higher lycopene content compared to callus cultured on MS and B5 basal media. Calli were presented as friable in WPM and B5 media, but they were compact on MS medium. The colors were pale yellow and light green in dark and light, respectively.

For callus incubated in the dark and light, lycopene content increased after two weeks of incubation and the maximum level of lycopene was achieved in the $5^{\text {th }}$ week

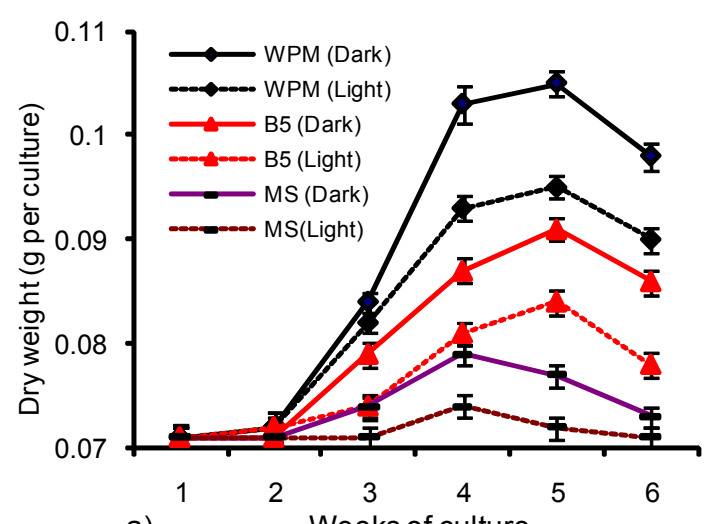

a) at $1.12 \pm 0.062$ and $0.33 \pm 0.021 \mathrm{mg} \mathrm{g}^{-1} \mathrm{DW}$ in light and dark, respectively which occurred during the stationary phase (weeks 4 and 5) of callus growth in both dark and light. Light induced lycopene production and maximum lycopene level incubated in light was higher than those incubated in darkness $(1.12 \pm 0.062$ and $0.33 \pm 0.021 \mathrm{mg}$ $\mathrm{g}^{-1} \mathrm{DW}$ under light and dark condition, respectively in the fifth week shown in Figure 2). Growth analysis and lycopene content of callus cultures revealed that lycopene production rate is directly related to the growth of calli.

The maximum level of lycopene was obtained on the basal B5 medium in the $3^{\text {rd }}$ week $(0.18 \pm 0.0043$ and 0.68 $\pm 0.012 \mathrm{mg} \mathrm{g}^{-1} \mathrm{DW}$ tissues in dark and light) (Figure 3 c,d). Subsequently, the amount of lycopene started to decrease from $3^{\text {rd }}$ week onwards. The basal B5 medium produced the highest biomass compared with the basal WPM and MS media in dark and light (Figure 5). The highest amount of lycopene $\left(0.165\right.$ and $0.69 \mathrm{mg} \mathrm{g}^{-1} \mathrm{DW}$ in dark and light, respectively) was detected in suspen-

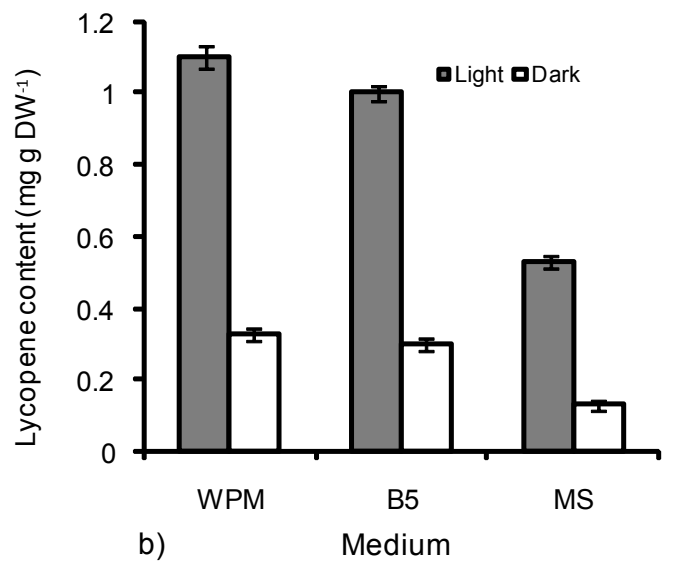

Figure 4 - Effects of three established basal media, WPM, MS and B5 on the biomass production in callus of Barringtonia racemosa (a) and lycopene production (b) in leaf derived callus of Barringtonia racemosa in media supplemented with $3 \%$ (w/v) of sucrose, $2 \mathrm{mg} \mathrm{L}^{-1}$ of 2,4-D incubated at $25^{\circ} \mathrm{C}$ under dark and light conditions. Data indicates mean \pm standard deviation $(\mathrm{n}=5)$.

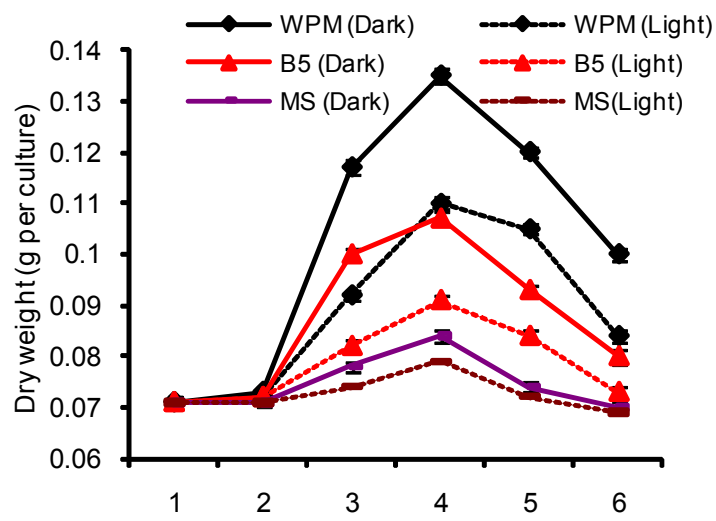

a) weeks of culture

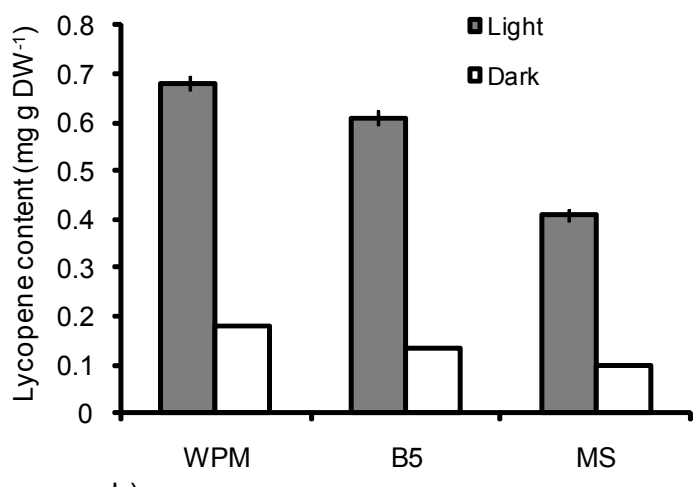

b)

Media

Figure 5 - Effects of three established basal media, WPM, MS and B5 on the biomass production and lycopene production in cell suspension cultures of Barringtonia racemosa (a) and lycopene production (b) in leaf derived callus of Barringtonia racemosa on media supplemented with $3 \%(\mathrm{w} / \mathrm{v})$ sucrose and $2 \mathrm{mg} \mathrm{L}^{-1} 2,4-\mathrm{D}$ incubated at $25^{\circ} \mathrm{C}$ in dark and light conditions. Data indicates as mean \pm standard deviation $(\mathrm{n}=5)$. 
sion cultures of the B5 basal medium. It was then followed by WPM and MS media yielded 0.125 and $0.1 \mathrm{mg}$ $\mathrm{g}^{-1} \mathrm{DW}$ of lycopene in light and 0.6 and $0.4 \mathrm{mg} \mathrm{g}^{-1} \mathrm{DW}$ in dark respectively.

Light had direct impact on the levels of lycopene in the culture for all treatments. The maximum level of lycopene in cell suspension incubated in the light condition was higher than those incubated in the dark condition for all treatments. Growth analysis and lycopene contents of cell suspension cultures demonstrated that the production of lycopene was highly growth-dependent on cell suspension culture.

\section{Discussion}

There is very strong callus induction with WPM. In attempts made to establish the 2,4-D concentration dependency of the formed calli, an inhibitory threshold was found at $2 \mathrm{mg} \mathrm{L}^{-1}$ (weight per volume). Although 2,4$\mathrm{D}$ is able to promote the growth of callus at high concentrations, it can inhibit the process, showing a herbicide-like activity as reported by Wernicke and Milkovits (1984).

The slower growth was obtained with the MS medium, and it could be due to the high content of ammonium salts, which have been reported as growth inhibitors for some plant tissue cultures (van Heerden et al., 1996; De Eknankul and Ellis, 1985). The reduced nitrogen related to production of digitoxin (Hagimori et al., 1983) in WPM and B5 culture media seems to play a vital role not only in the in vitro growth response but also on the biosynthetic capacity of lycopene in B. racemosa. We assessed the profile of callus growth and found the peak for growth. WPM was better than two other media at the maximum of growth. The decrease in the amount of callus by WPM media after the fifth week could be due to the limited supply of nutrient in a solid medium (Immonen, 1996; Hagimori et al., 1983). However, the limited supply of nutrients could lead to somatic embryogenesis and secondary metabolite formation, as was reported for neem (Akula et al., 2003).

The growth of $B$. racemosa cell suspension illustrated a rapid and highest biomass response frequently with B5 basal medium than reported for other cultures. Tropaeolum majus callus cultures also indicated a similar result (Pintao and Pais, 1994). The data presented suggests that the basal $\mathrm{B} 5+2 \mathrm{mg} \mathrm{L}^{-1}$ (weight per volume) 2,4-D caused the maximum growth rate in the fourth week. A good reason for good results for B5 was mentioned as half the level of $\mathrm{NH}_{4}^{+}$compared to WPM (Fisichella et al., 2000).

WPM basal medium obtained the highest lycopene content from calli cultures versus MS with the lowest. This is perhaps due to the higher concentration of ammonium ion in MS medium than WPM and B5 media. Interestingly, the growth-dependent production of lycopene in callus cultures was demonstrated. Also, determining of cell growth and lycopene content in cell suspension cultures of $B$. racemosa was studied similarly to callus cultures. Lycopene production from cell suspension cultures was lower in amount compared to the production of the phytochemical from callus cultures. Callus cultures are usually more productive than cell suspension cultures with the same origin cultivated in the same medium composition (Enderâ, 1994). The highest amount of lycopene was obtained further by the B5 basal medium. This could be due to the favorable ratio of $\mathrm{NO}_{3} / \mathrm{NH}_{3}$ found in $\mathrm{B} 5$ media, as its effect has been reported to favor secondary metabolism (Kirby et al., 1987).

2-(4-chlorophenylthio)-triethylamine (CPTA) was used to increase lycopene formation to levels approximating those in field-or glasshouse grown fruit, and then growth regulators, sucrose and temperature were used to regulate lycopene accumulation. The native auxin indole-3- acetic acid (IAA) was more effective than 2,4$\mathrm{D}$ in promoting lycopene formation, sucrose inhibited lycopene formation (cell basis), and temperature produced a pattern similar to that observed in the field with a temperature optimum between 18 and $26^{\circ} \mathrm{C}$. Suggestions for further improvements in technique are included (Robertson et al., 1995).

In another study, the potential role of 2-methyl imidazole in improving lycopene production by Blakeslea trispora with regards to yield, selectivity, and safety aspects was investigated in batch culture. Optimization of the bioprocess conditions in terms of (i) $(+)$ and (") strain ratio in the inoculum, (ii) initial crude soybean oil (CSO) addition level, and (iii) the amount of 2-methyl imidazole was based on response surface methodology to achieve maximum lycopene production. The dependence of growth kinetics, lycopene yield, and selectivity of the bioprocess on the above factors was clear (Pegklidou et al., 2008). Also, the effects of light and dark on lycopene formation and cell growth were examined by callus culture of $B$. racemosa in this study. The callogenesis efficiency of both callus and cell suspension culture incubated in the dark condition was relatively higher compared to those incubated in the light condition. In this study, light has a negative effect on the growth of callus. The dry weight of callus and cell suspension incubated in darkness was higher compared to that in the light condition.

Chong and Taper (1974) found that Cortland callus grew better in dark whereas growth of Robusta was not influenced by light. Light did not influence growth of McIntosh callus between o and 3,350 lx, although slight stimulation in growth occurred at $7800 \mathrm{~lx}$. But Smith (1977) observed that Gossypium arboreum L. Callus proliferation was superior under high light (8000 to 9000 lux) conditions at $29 \pm 1{ }^{\circ} \mathrm{C}$. Kevers et al. (1995) observed that darkness improves growth and delays necrosis in a nonchlorophyllous habituated (HNO) sugar beet (Beta vulgaris L.) callus. It appeared that darkness allowed the HNO callus to avoid the photooxidation stress. Therefore, the favorable effect of darkness on HNO growth might be explained by the suppression of photooxidative damage due to the absence of carotenoids. The higher 
peroxidase activity in the $\mathrm{HNO}$ callus maintained in darkness raised the problem of heme synthesis in this heterotrophic callus.

Light strongly influences many aspects of growth in plants. There have, however, been few studies on the effects of light on cell division in non-green plant tissue cultures. In the course of investigating the physiology of cell division in developing callus cultures of Helianthus tuberosus it has been observed that light can have an inhibitory effect on cell division (Fraser at al., 1967). White light, which is effective only in the presence of 2,4-D and during the period before the onset of DNA replication, is required only in small amounts to promote a maximum effect, although inhibition of cell division was never complete Light does not interfere with the timing of the cell cycle but exerts an influence on the size of the dividing population. The results are consistent with a hypothesis which postulates that a substance or substances essential for cell division is reduced in amount by exposure to light. The extent of the first synchronous division is probably therefore determined by the supply of this substance (Yeoman and Davidson, 1971).

The light was optimal for the production of lycopene in cell suspension and callus compared to the dark. The peak of lycopene was in callus in $5^{\text {th }}$ week and in cell suspension in third week obtained. Stimulation of lycopene synthesis in plant tissue cultures when incubated in the light condition could be associated with the activation of $z$-carotene desaturase (Glenn and Winterbourn, 1998). Both dark and light caused an increase in lycopene production from callus cultures during the stationary phase but light were more effective with $41.2 \%$ of higher lycopene production $(p<0.05)$. Further, WPM basal medium obtained the highest lycopene content from calli cultures versus MS with the lowest in both dark and light.

The influence of the physicochemical environment of the explant during culture is as important as that of the biotic factors. The composition of the culture medium and physical factors such as light, temperature, and humidity can greatly affect the developmental pathway of the cultured cells and preclude attainment of desired morphogenesis and morphogenesis efficiency (Khachatourians and George, 2001).

Regarding culture media, the highest amount of lycopene was obtained further by the B5 basal medium both in dark and light. Light as a very important physical factor may stimulate the production of secondary metabolites (Matsumoto et al., 1994) in many plant cell cultures. Similarly, in Perilla frutescens, the stimulatory effect of light on the formation of anthocyanins has been reported (Zhong and Seki, 1991). The synthesis of secondary metabolites in plants is part of the defense responses of plants to stress. Light source, which can create stresses on plant cells, may act as an elicitor of plant defense response so as to stimulate the secondary metabolite synthesis. The effect of light on natural product biosynthesis is quite varied. Light usually induces chloroplast differentiation, which sometimes leads to elevation of secondary metabolism. Light is often essential to induce anthocyanin biosynthesis, although its biosynthesis is not localized in chloroplasts (Mittler, 2002). On the other hand, light is a stimulus that activates a broad range of plant genes related to photosynthesis and photomorphogenesis. Carotenoids are required during photosynthesis in plants and algae, and, therefore, genes that direct the biosynthesis of carotenoids in these organisms are also regulated by light (Pizarro and Stange, 2009).

\section{Conclusion}

The best media formulations supplemented with appropriate concentrations of growth regulator for growth and lycopene production were established during early phases of callus and cell suspension cultures of $B$. racemosa. The time course analysis of growth and lycopene accumulation indicated a growth dependency of the accumulation of this carotenoid; however, a higher production was always associated with light-grown cultures.

\section{Acknowledgements}

This work was supported by Isfahan University Research grant.

\section{References}

Akula, C.; Akula, A.; Drew, R. 2003. Somatic embryogenesis in clonal neem, Azadirachta indica A. Juss., and analysis for in vitro azadirachtin production. In vitro Cellular and Developmental Biology 39: 304-310.

Behbahani, M.; Ali, A.M.; Muse, R. 2007a. Plant regeneration from leaf explants of Barringtonia racemosa. Journal of Medicinal Plants Research 5: 103-108.

Behbahani, M.; Ali, A.M.; Muse, R.; Mohd, N.B. 2007b. Antioxidant and anti-inflammatory activities of leaves of Barringtonia racemosa. Journal of Medicinal Plants Research 5: 95-102.

Chong, C.; Taper, C.D. 1974. Influence of light intensity on sorbitol metabolism, growth, and chlorophyll content of malus tissue cultures. Annals of Botany 38: 359-362.

Enderß, R. 1994. Plant Cell Biotechnology. Springer Verlag, Berlin, Germany.

Fisichella, M.; Silvi, E.; Morini, S. 2000. Regeneration of somatic embryos and roots from quince leaves cultured on media with different macroelement composition. Plant Cell, Tissue and Organ Culture 63: 101-107.

Fraser, R.S.S.; Loening, U.E.; Yeoman, M.M. 1967. Effect of light on cell division in plant tissue cultures. Nature 215: 873.

Gamborg, O.L.; Miller, R.A.; Ojima, K. 1968. Nutrient requirements of suspension cultures of soybean root cells. Experimental Cell Research 50: 151-158.

Glenn, F.V.; Winterbourn, C. 1998. Inhibition of adriamycinpromoted microsomal lipid peroxidation by â-carotene, átocopherol and retinol at high and low oxygen partial pressures. Ferbs Letters 238: 353-356.

Hagimori, M.; Matsumoto, T.; Obi, Y. 1983. Effects of mineral salts, initial $\mathrm{pH}$ and precursors on digitoxin formation by shootfroming cultures of Digitalis purpurea L. grown in liquid media. Agricultural and Biological Chemistry 47: 565-571. 
Immonen, A.S.T. 1996. Influence of media and growth regulators on somatic embryogenesis and plant regeneration for production of primary triticales. Plant Cell, Tissue and Organ Culture 44: $45-52$.

Kevers, C.; Bisbis, B.; Le Dily, F.; Billard, J.P.; Huault, C.; Gaspar, T.H. 1995. Darkness improves growth and delays necrosis in a nonchlorophyllous habituated sugarbeet callus: Biochemical changes. In Vitro Cellular and Developmental Biology. Plant 31: 122-126.

Khachatourians, G.; George, G. 2001. Transgenic plants and crops. Marcel Dekker, New York, NY, USA. p. 76-156.

Khan, S.; Jabbar, A.; Hasan, C.M.; Rashid, M.A. 2000. Antibacterial activity of Barringtonia racemosa. Fitoterapia 72: 162-164.

Kirby, E.G.; Leustek, T.; Lee, M.S. 1987. General Principles and Biotechnology. p. 67-88. In: J.M. Bonga; D.J. Durzan, eds. Cell and tissue culture in forestry. Martinus Nijhoff, Dordrecht, Germany.

MacKeen, M.M.; Ali, A.M.; El-Sharkawy, S.H.; Manap, M.Y.; Salleh, K.M.; Lajis, N.H.; Kawazu, K. 1997. Antimicrobial and cytotoxic properties of some Malaysian traditional vegetables (ULAM). International Journal of Pharmacognosy 35: 174-178.

Matsumoto, H.; Tanida, Y.; Ishizuka, K. 1994. Porphyrin intermediate involved in herbicidal action of ä-aminolevulinic acid on duckweed (Lemna paucicostata Hegelm). Journal of Pesticide Biochemistry and Physiology 48: 214-221.

Mittler, R. 2002. Oxidative stress, antioxidants and stress tolerance. Trends in Plant Science 7: 405-410.

Murashige, T.; Skoog, F.A. 1962. A revised medium for a rapid growth and bioassays with tobacco tissues cultures. Physiology Plantarum 15: 473-497.

Pavingerova, D.; Sediva J. 1999. The possibility of micropropagation and Agrobacterium-mediated transformation of Kalmia latifolia. Biologia Plantarun 42: 441-444

Pegklidou, K.; Mantzouridou, F.; Tsimidou, M.Z. 2008. Lycopene production using Blakeslea trispora in the presence of 2-Methyl Imidazole: yield, selectivity, and safety aspects. Journal of Agriculture and Food Chemistry 56: 4482-4490.
Pintao, A.M.; Pais, M.S.S. 1994. Cell suspension cultures from Tropaeolum majus L. establishement and growth conditions. Bioresource Technology 47: 143-147.

Pizarro, L.; Stange, C. 2009. Light-dependent regulation of carotenoid biosynthesis in plants. Ciencia e Invesigación Agraria 36: 143-162.

Robertson, G.H.; Mahoney, N.E.; Goodman, N.; Pavlath, A.E. 1995. Regulation of lycopene formation in cell suspension culture of VFNT tomato (Lycopersicon esculentum) by CPTA, growth regulators, sucrose, and temperature. Journal of Experimental Botany 46: 667-673.

Smith, R.H.; Price, H.J.; Thaxton, J.B. 1997. Defined conditions for the initiation and growth of cotton callus in vitro I. Gossypium arboretum. In Vitro Cellular and Development Biology-Plant 13: 329-334

Thomas, T.; Panikkar, J.B.; Subramoniam, A.; Krishan, N.M.; Panikkar, K.R. 2002. Antitumour property and toxicity of Barringtonia racemosa Roxb. seed extract in mice. Journal of Ethnopharmacology 82: 223-227.

Welsch, R.; Beyer, P.; Huguency, P.; Kleining, H., Von Lintig, J. 2001. Regulation and activation of phytoene synthase, a key enzyme in carotenoid biosynthesis, during photomorphogenesis. Journal of Plantarum 211: 846-854.

Wernicke, W.; Milkovits, L. 1984. Developmental gradients in wheat leaves: response of leaf segments in different genotypes cultured in vitro. Journal of Plant Physiology 115: 49-58.

Yeoman, M.M.; Davidson, A.W. 1971. Effect of light on cell division in developing callus cultures. Annals of Botany 35: 1085-1100.

Zhao, Y.; Yu, W.; Hu, W.; Yuan, Y. 2003. Anti-inflammatory and anticoagulant activities of lycopene in mice. Nutrition Research 23: 1591-1595.

Zhong, J.; Seki, T. 1991. Effect of light irradiation on anthovyanin production by suspended culture of Perilla frutescens. Biotechnology and Bioengineering 38: 653-658.

Received September 03, 2009

Accepted May 31, 2010 